\title{
Natural Cannabinoids Improve Dopamine Neurotransmission and Tau and Amyloid Pathology in a Mouse Model of Tauopathy
}

\author{
Maria J. Casarejos ${ }^{\mathrm{a}, \mathrm{e}, 1}$, Juan Perucho ${ }^{\mathrm{a}, \mathrm{e}, 1}$, Ana Gomez $^{\mathrm{a}, \mathrm{e}}$, Maria P. Muñoz $^{\mathrm{a}, \mathrm{e}}$, Marian \\ Fernandez-Estevez $^{\mathrm{a}, \mathrm{e}}$, Onintza Sagredo ${ }^{\mathrm{c}, \mathrm{e}}$, Javier Fernandez Ruiz $^{\mathrm{c}, \mathrm{e}}$, Manuel Guzman ${ }^{\mathrm{d}, \mathrm{e}}$, \\ Justo Garcia de Yebenes ${ }^{\mathrm{b}, \mathrm{e}}$ and Maria A. Mena ${ }^{\mathrm{a}, \mathrm{e}, *}$ \\ ${ }^{a}$ Departments of Neurobiology, Ramon y Cajal University Hospital, Madrid, Spain \\ ${ }^{\mathrm{b}}$ Departments of Neurology, Ramon y Cajal University Hospital, Madrid, Spain \\ ${ }^{\mathrm{c}}$ Department of Biochemistry and Molecular Biology, School of Medicine, UCM, Madrid, Spain \\ ${ }^{\mathrm{d}}$ Department of Biochemistry and Molecular Biology, School of Biology, UCM, Madrid, Spain \\ ${ }^{\mathrm{e}}$ CIBERNED, Spain
}

Accepted 4 February 2013

\begin{abstract}
Cannabinoids are neuroprotective in models of neurodegenerative dementias. Their effects are mostly mediated through CB1 and CB2 receptor-dependent modulation of excitotoxicity, inflammation, oxidative stress, and other processes. We tested the effects of Sativex ${ }^{\circledR}$, a mixture of $\Delta^{9}$-tetrahydrocannabinol and cannabidiol, acting on both CB1 and CB2 receptors, in parkin-null, human tau overexpressing $\left(\mathrm{PK}^{-/-} / \mathrm{Tau}^{\mathrm{VLW}}\right)$ mice, a model of complex frontotemporal dementia, parkinsonism, and lower motor neuron disease. The animals received Sativex ${ }^{\circledR}, 4.63 \mathrm{mg} / \mathrm{kg}$, ip, daily, for one month, at six months of age, at the onset of the clinical symptoms. We evaluated the effects of Sativex ${ }^{\circledR}$ on behavior, dopamine neurotransmission, glial activation, redox state, mitochondrial activity, and deposition of abnormal proteins. $\mathrm{PK}^{-/-} / \mathrm{Tau}^{\mathrm{VLW}}$ mice developed the neurological deficits, but those treated with Sativex ${ }^{\circledR}$ showed less abnormal behaviors related to stress, less auto and hetero-aggression, and less stereotypy. Sativex ${ }^{\circledR}$ significantly reduced the intraneuronal, MAO-related free radicals produced during dopamine metabolism in the limbic system. Sativex ${ }^{\circledR}$ also decreased gliosis in cortex and hippocampus, increased the ratio reduced/oxidized glutathione in the limbic system, reduced the levels of iNOS, and increased those of complex IV in the cerebral cortex. With regard to tau and amyloid pathology, Sativex ${ }^{\circledR}$ reduced the deposition of both in the hippocampus and cerebral cortex of $\mathrm{PK}^{-/-} / \mathrm{Tau}^{\mathrm{VLW}}$ mice and increased autophagy. Sativex ${ }^{\circledR}$, even after a short administration in animals with present behavioral and pathological abnormalities, improves the phenotype, the oxidative stress, and the deposition of proteins in $\mathrm{PK}^{-/-} / \mathrm{Tau}^{\mathrm{VLW}}$ mice, a model of complex neurodegenerative disorders.
\end{abstract}

Keywords: Amyloid, autophagy, cannabinoids, dopamine, frontotemporal dementia, lower motor neuron disease, parkin, parkinsonism, reactive oxygen species, Sativex ${ }^{\circledR}$, tau

Supplementary data available online: http://dx.doi.org/10.3233/JAD-130050

\footnotetext{
${ }^{1}$ These authors contributed equally to this work.

*Correspondence to: Dr. M.A. Mena, Department of Neurobiology, Hospital Ramón y Cajal, Ctra. de Colmenar, Km. 9, Madrid 28034, Spain. Tel.: +349133683 84; Fax: +349133690 16; E-mail: maria.a.mena@hrc.es.
}

\section{INTRODUCTION}

The pharmacological manipulation of the cannabinoid system is considered as a putative neuroprotective strategy in some neurodegenerative disorders, including Alzheimer's disease, Parkinson's disease, and 
Huntington's disease [1-17]. The neuroprotective effects of cannabinoids are mediated through CB1 receptors, located in neurons, which modulate neuronal function, and $\mathrm{CB} 2$ receptors, mostly located in microglia, which play an important role in neuroinflammation. For instance, the activation of the CB2 receptors increases the removal of amyloid by human macrophages in vitro [18]. Cannabinoids have been postulated to increase neurogenesis in the adult brain, and to protect neurons from excitotoxicity, calcium influx, inflammation, and ischemia. These mechanisms have been postulated in the pathogenesis of Alzheimer's disease and, therefore, cannabinoids may have beneficial effects in this disease [4, 7, 13-15]. Additional mechanisms of action, including activation of peroxisome proliferator-activated receptors and modulation of mitochondrial activity and oxidative stress, could also contribute to cannabinoid-induced neuroprotection [19-21].

The majority of the studies showing neuroprotective effects of cannabinoids have been performed in monogenic or pharmacological models of neurodegenerative diseases. However, very little is known about potential neuroprotective effects of these compounds on complex models of neurodegenerative diseases, which represent the complexity of the human diseases more faithfully. Sativex ${ }^{\circledR}$ is a cannabinoid-based medicine already approved for the treatment of spasticity in multiple sclerosis $[22,23]$. Sativex ${ }^{\circledR}$ is a mixture of $\Delta^{9}$-tetrahydrocannabinol (THC) and cannabidiol (CBD). It combines several potential neuroprotective effects, such as the stimulation of both $\mathrm{CB} 1$ and $\mathrm{CB} 2$ receptors by $\mathrm{THC}$ with the antioxidant effects of CBD [24]. Sativex ${ }^{\circledR}$ is therefore especially adequate for the study of neuroprotective effects of cannabinoids on $\mathrm{PK}^{-/-} / \mathrm{Tau}^{\mathrm{VLW}}$ mice, a complex model of tauopathy, which has been previously described [25] and which combines cerebral and peripheral deposition of amyloid with lesions of the hippocampus, substantia nigra, and lower motor neuron and resembles a multisystemic neurological disease such as frontotemporal dementia with parkinsonism and amyotrophy [25-28]. These mice have lower levels of c-terminal HSP70 interacting protein (CHIP-HSP70), involved in the proteosomal degradation of tau, increased oxidative stress, measured as depletion of glutathione which, added to lack of parkin, could trigger tau accumulation and amyloidogenesis.

This model is the first that demonstrates amyloid$\beta$ (A $\beta)$ deposits caused by overexpression of tau and without modification of the amyloid- $\beta$ protein precursor, presenilins, or secretases. $\mathrm{PK}^{-/-} / \mathrm{Tau}^{\mathrm{VLW}}$ mice provide a link between the two proteins more important for the pathogenesis of Alzheimer's disease [25-28].

The interest of testing the effects of cannabinoids on these animals is further increased by the fact that parkin-null mice have early down-regulation of the CB1 receptor in striatum followed by a posterior upregulation at the time when these animals develop pathology [29].

The aim of this study was to investigate the effects of Sativex ${ }^{\circledR}$ on the behavioral and biochemical abnormalities observed in $\mathrm{PK}^{-/-} / \mathrm{Tau}^{\mathrm{vlw}}$ mice. We examined the levels of monoamines and metabolites in mouse brain, phosphorylated tau-positive neuritic plaques, neurofibrillary tangles, astrogliosis, and microgliosis as well as plaques of murine $A \beta$ in the cerebral cortex and hippocampus. Furthermore, we investigated the oxidative metabolism and autophagy-mediated mechanisms.

\section{MATERIAL AND METHODS}

\section{Transgenic animals, cannabinoid treatment, and tissue collection}

Our experiments were performed on littermates generated by a heterozygote intercross of human-mutated tau overexpressing mice $\left(\mathrm{Tau}^{\mathrm{VLW}}\right)$, overexpressing a human four-repeat tau isoform carrying three mutations (G272V, P301L, and R406W) linked to frontotemporal dementia FTD-17 and the parkin-null mutant mice $\left(\mathrm{PK}^{-/-}\right)$as previously described $[25,26]$. Mice were obtained by breeding the animals according to the schema shown in Supplementary Figure 1 (available online: http://www.j-alz.com/issues/35/vol353.html\#supplementarydata02).

Then, we obtained the $\mathrm{PK}^{-/-} / \mathrm{Tau}^{\text {vlw }}$ homozygote strain selecting them after a heterozygote intercross. The animals therefore have the same genetic background. The confirmation of the genotype in each mouse was performed by standard PCR techniques of genomic DNA obtained from its tail, marking every animal with a specific chip number (Supplementary Figure 1). Eighteen male mice were used, half of them being injected intraperitonealy (i.p.) with Sativex ${ }^{\circledR}$ and half with saline for controls (9:9). All mice were used for behavioral experiments (depending on the specific trial); twelve males for biochemical, monoamines, and glutathione and six for histological assays. The Sativex ${ }^{\circledR}$ treatment was administrated for a month, starting at 6 months of age and the animals were sacrificed at 7 months. Procedures using laboratory animals were in accordance with the European Union Directives and the Ramón y Cajal University Hospital 
Animal Care Committee. The mice were housed 9 per cage, in an enriched environment with tissue paper and cardboard tubes. All efforts were made to minimize the number of animals used and their suffering.

Sativex ${ }^{\circledR}$ is a drug whose principal active components are the cannabinoids THC and CBD. It is generated by mixing a THC botanical extract (containing $67.1 \%$ THC, $0.3 \%$ CBD, $0.9 \%$ cannabigerol, $0.9 \%$ cannabichromene, and $1.9 \%$ other phytocannabinoids) and a CBD botanical extract (containing $64.8 \%$ CBD, $2.3 \%$ THC, $1.1 \%$ cannabigerol, $3.0 \%$ cannabichromene, and $1.5 \%$ other phytocannabinoids) (both provided by GW Pharmaceuticals Ltd, Cambridge, UK) in a 1:1 proportion. The extracts were dissolved in ethanol and mixed 1:1 to make a $20 \mathrm{mg} / \mathrm{ml}$ Sativex ${ }^{\circledR}$ stock solution in siliconed tubes and covered in order to protect it from direct light. The Sativex ${ }^{\circledR}$ solution was prepared as previously described [2, $10,17]$. The total dose of cannabinoid administered was always $4.63 \mathrm{mg} / \mathrm{kg}$ of Sativex ${ }^{\circledR}$ (equivalent to $1.5 \mathrm{mg} / \mathrm{kg}$ of pure CBD and $1.5 \mathrm{mg} / \mathrm{kg}$ of pure THC), which is within the range of effective doses of both compounds when they were administered in pure form in other experimental models of neurodegenerative diseases [2, 10, 17] and in human studies [30]. This was also the effective dose in a previous study with Sative ${ }^{\circledR}$-like combination of phytocannabinoids in a model of Huntington's disease [17]. The vehicle (Tween-80:Saline) was prepared in a similar manner, except that the drug was omitted. Solutions were freshly made every day and administered in $1 \mathrm{ml} / \mathrm{kg}$ body weight. Mice were subjected to i.p. injections of Sativex ${ }^{\circledR}$ or vehicle for 30 days, with one injection per day always between 10:00 and 11:00 AM.

Six mice of each experimental group were used for biochemical studies and three for histology. Motor, cognitive, and anxiety behavioral testing was performed every week. At the end of the treatment, the mice were sacrificed and their brains were dissected in different brain regions which were used for the analysis of the metabolism of monoamines, protein expression, and the levels of glutathione. Three mice of each experimental group were perfused with $4 \%$ paraformaldehyde and used for histological studies (see below).

\section{Genotype determination by PCR}

$\mathrm{PK}^{-/-} / \mathrm{Tau}^{\mathrm{VLW}}$ mice were genotyped by PCR screening (Supplementary Figure 1). Genomic DNA was extracted from mouse tail after proteinase $\mathrm{K}$ digestion $\left(16 \mathrm{~h}\right.$ at $\left.55^{\circ} \mathrm{C}\right)$ in lysis buffer $(50 \mathrm{mM}$ Tris- $\mathrm{HCl}$
$\mathrm{pH} 8.3,100 \mathrm{mM} \mathrm{NaCl}, 5 \mathrm{mM}$ EDTA, $0.8 \%$ SDS) and phenol/chloroformisoamyl alcohol (25:24:1 ratio) extraction, followed by DNA precipitation with $1 / 10$ volume of $3 \mathrm{M}$ sodium acetate ( $\mathrm{pH} 5.2$ ), and 1 volume of absolute ethanol. The pellet was washed with $70 \%$ ethanol and allowed to air-dry. The nucleic acids were dissolved in $150 \mu$ l of sterile water. For PCR, $150 \mathrm{ng}$ of genomic DNA was denatured for $3 \mathrm{~min}$ at $94^{\circ} \mathrm{C}$ and subjected to 35 cycles of $1 \mathrm{~min}$ at $94^{\circ} \mathrm{C}$, $1 \mathrm{~min}$ at $53^{\circ} \mathrm{C}$, and $1 \mathrm{~min}$ at $72^{\circ} \mathrm{C}$, followed by $5 \mathrm{~min}$ of a final extension at $72^{\circ} \mathrm{C}$. PCR was performed in a final volume of $40 \mu \mathrm{l}$ containing $1 \mathrm{U}$ of Taq DNA polymerase (Promega; $5 \mathrm{U} / \mu \mathrm{l}), 1 \mathrm{mM}$ dNTP $(4 \times 0.25 \mathrm{mM})$, $2.5 \mathrm{mM} \mathrm{MgCl} 2,5 \mathrm{mM}$ Tris- $\mathrm{HCl}$ (pH 8.0), and $1 \mu \mathrm{l}$ of specific sense and antisense primers at $50 \mathrm{ng} / \mu \mathrm{l}$ (listed below):

\section{PK1F: TGC TCT GGG GTT CGT C TT1: CTC TGC CCT CTG TTC TCT GG \\ PK2F: TTG TIT TGC CAA GTT CTA AT \\ TT2: CCT GTC CCC CAA CCC GTA CG \\ PKR: TCC ACT GGC AGA GTA AAT GT \\ THY: CGC TGA TGG CTG GGT TCA TG}

Twenty-microliter volumes of PCR products were analyzed by electrophoresis on a $1.8 \%$ agarose gel that was subsequently stained with ethidium bromide for visualization of DNA bands. DNA molecular weight markers (Roche, Spain) were used to provide a size reference for the test reactions [25, 26].

\section{Behavioral studies}

Exploratory behavior, social interaction, motor activity, food and water intake as well as body weight were measured during the experiment.

\section{Actimeter}

In order to analyze the motor activity, a computerized actimeter was used (Actitrack, Panlab, Barcelona, Spain). This allows for the analysis of the distance run in the actimeter (ambulation) and the zonal distribution of the movement (anxiety and exploratory index). The exploratory index is inversely proportional to the time spent and the distance traveled in the central area away from the walls. The analysis of motor activity was done for a period of 10 minutes.

\section{Marble-burying test}

The animals were transported from their site cages to the test site for 30 minutes of acclimation period prior to the start of the experiment. Tests were performed between 18:00 and 20:00 hours, in semi-light 
in order to equal the 12:12 hour dark/light cycle of their vivarium. The mice were placed individually in plastic cages identical to their home cages, but without food or water, and with 9 marbles in 3 lines of 3 placed at equal distances between them. The animals were tested at the same time to avoid a potential confound of a within-cage order effect. A new cage, clean marbles, and fresh bedding were used for each mouse. Mice were placed in their test cages and left undisturbed for 30 minutes. At the end of that time, the number of marbles was recorded as: uncovered, buried completely, 2/3 covered, and half covered. This classification was used to obtain a "buried index", as an indication of anxiolytic-like activity.

\section{Grooming activity after water mist spray}

The usual grooming routine may involve a mouse scratching itself with its hind feet; washing itself by spreading saliva on its hands and rubbing them over its face and fur; and grooming with its teeth. In normal conditions, low-stress comfort grooming is a spontaneous body care ritual, which occurs in a transition from rest to activity, and is a typical behavioral marker of low or no stress [31]. Each mouse was subjected to one squirt of sterile water mist spray to start a grooming conduct and this grooming activity was recorded for 5 minutes immediately after the mist spray. Once the test started, the percentage of the 5 minutes that the mice are in grooming activity was measured. The experimenters were blind to the mice with or without Sative ${ }^{\circledR}$ treatment.

\section{Self-injurious behavior}

Barbering, or whisker removal, may represent stress-evoked behavioral response [32]. In most cases, it affects whiskers, a crucial sensor system of external information in mice. However, an abnormal barbering conduct, as seen in $\mathrm{PK}^{-/-} / \mathrm{Tau}^{\mathrm{vlw}}$ mice [25], may be due to a pathological neurobiological status in mice and a compulsive behavior because it represents a part of the waking activity of the mice [33]. This $\mathrm{PK}^{-/-} / \mathrm{Tau}^{\mathrm{vlw}}$ model showed an elevated level of self-injured wounds on the front of the face, due to their compulsive behavior and repetitive selfscratching [25]. The role of cannabinoids in mood and anxiety disorders has been described [34-36]. Each mouse was recorded to evaluate the extent of facial barbering in the different groups of the experiment.

\section{Rota-rod}

Motor coordination was evaluated in the Rota-Rod. The mice walked on a rod in movement, and after two tests of adaptation and a rest period, the mice performed three trials on the rod with a maximum time of 3 minutes at constant speed, and alternating breaks between trials. On the same day, the motor coordination was evaluated by the time of permanence (seconds) in the Rota-Rod with constant acceleration.

\section{Y-maze}

The spontaneous alternation behavior of mice in a Ymaze was used to measure short-term memory, motor activity, and anxiety. Each mouse was placed at the end of an arm and allowed to move freely throughout the maze during a 5-minutes session. The arm entries were recorded visually and with video (taping). General activity was measured as the total number of arm entries, while the basic mnemonic function was measured as the percentage of spontaneous alternation. Alternation was defined as successive entries into the three arms on overlapping triplet sets. The alternation behavior (\%) was calculated as the ratio of actual alternations to possible alternations (defined as the total number of arm entries minus two), multiplied by 100 .

\section{Determination of monoamines and their metabolites}

After decapitation, the brains were dissected as described [26]. The limbic, striatum, and midbrain brain regions were frozen on dry ice and the levels of monoamines and their metabolites were measured by HPLC with an ESA coulochem detector [26]. The following compounds were analyzed: 3-methoxytyramine (3-MT), 3,4-dihydroxyphenylacetic acid (DOPAC) and homovanillic acid (HVA), noradrenaline (NA), serotonin (5-HT) and its metabolite, 5-hydroxyindole-acetic acid (5-HIAA). Briefly, the tissue was sonicated in 6 volumes (weight/volume) of $0.4 \mathrm{~N}$ perchloric acid (PCA) with $0.5 \mathrm{mM} \mathrm{Na} 2 \mathrm{~S}_{2} \mathrm{O}_{5}$ and $2 \%$ EDTA and then centrifuged at $10,000 \times \mathrm{g}$ at $4^{\circ} \mathrm{C}$ for 20 minutes. Monoamine levels were determined from $20 \mu \mathrm{l}$ of the resulting supernatant. The chromatographic conditions were as follows: a column (Nucleosil 5C18); the mobile phase, a citrate/acetate buffer $0.1 \mathrm{M}, \mathrm{pH} 3.9$ with $10 \%$ methanol, 1 mM EDTA, and $1.2 \mathrm{mM}$ heptane sulfonic acid; and the detector voltage conditions: D1 (+0.05), D2 (-0.39), and the guard cell $(+0.40)$.

\section{Glutathione measurements}

Total glutathione (GSx) levels were measured by the method of Tietze [37]. A sample $(40 \mu \mathrm{l})$ of the 
supernatant of homogenated limbic, striatum, and midbrain regions in $0.4 \mathrm{~N}$ PCA was neutralized with 4 volumes of phosphate buffer $\left(0.2 \mathrm{M} \mathrm{NaH}_{2} \mathrm{PO}_{4}, 0.2 \mathrm{M}\right.$ $\mathrm{Na}_{2} \mathrm{HPO}_{4}, 0.5 \mathrm{M}$ EDTA, and $\mathrm{pH} 7.5$ ). Fifty microlitres of the resulting preparation were mixed with DTNB (0.6 mM), NADPH $(0.2 \mathrm{mM})$, and glutathione reductase (1U), and the reaction was monitored in a P96 automatic microtiter reader at $405 \mathrm{~nm}$ for 6 minutes. Oxidized glutathione (GSSG) was measured by the method of Griffith [38]. After neutralization with the phosphate buffer, the remaining sample $(110 \mu \mathrm{l})$ was mixed with 2-vinylpyridine $(1.1 \mu \mathrm{l})$ at room temperature for 1 hour, and the reaction was carried out as described above. Reduced glutathione (GSH) was obtained by subtracting GSSG levels from GSx levels.

\section{Histological studies}

\section{Immunohistochemistry}

The animals were anesthetized i.p. with a mixture (5:4:1) of ketamine $(50 \mathrm{mg} / \mathrm{ml})$, diazepam $(1 \mathrm{mg} / \mathrm{ml})$, and atropine $(1 \mathrm{mg} / \mathrm{ml})$ and perfused with $4 \%$ paraformaldehyde in PBS. After that, the whole brain was included in paraffin, sectioned in the microtome at a thickness of 4 microns. We used a rabbit polyclonal anti-A $\beta_{1-42}$ (Abcam) diluted 1:200 for amyloid plaque evaluation. Mouse monoclonal anti tau-5 antibody diluted 1:100 was from Chemicon (Madrid, Spain). Rabbit polyclonal anti-Iba1 antibody, diluted 1:300, was from WAKO (Neuss, Germany). Rabbit polyclonal anti-glial fibrillary acidic protein (GFAP) antibody diluted 1:500 was from Dako (Denmark). Anti-rabbit and anti-mouse secondary antibodies were from Dako (Denmark). The number of immunoreactive amyloid plaques, tau positive plaques, and cells with neurofibrillary tangles in cortex and hippocampus were counted in an Olympus Bx51 stereological microscope, using Cast Grid software.

\section{Astroglial and microglial analysis}

The intensity and the area of fluorescence of GFAP ${ }^{+}$ immunostaining were measured in 20 pre-defined fields for each slide, processed with the automatic software Image-Pro 6.2 (Media Cybernetics, Silver Spring, MD, USA) and expressed as arbitrary units or intensity (integrated optical density). The representative images of the GFAP staining were of the dental gyrus in the hippocampus. The number and morphology of microglia cells were assessed by Iba1 staining in hippocampus and cerebral cortex. For all immunohistochemistry methods, negative controls were tested by incubation without the primary antibody in each case.

\section{Protein analysis}

The different brain regions were sonicated (VibraCell, level 2 for 30 seconds) in six volumes (W/V) of $0.4 \mathrm{~N}$ perchloric acid with $0.5 \mathrm{mM} \mathrm{Na}_{2} \mathrm{~S}_{2} \mathrm{O}_{5}$ and $2 \%$ EDTA and then centrifuged at $12000 \mathrm{rpm}$ for 20 minutes at $4{ }^{\circ} \mathrm{C}$. The pellet, with the proteins, was neutralized $(\mathrm{W} / \mathrm{V}=1 / 6)$ with the lysis buffer $(0.75 \%$ $\mathrm{Na} 2 \mathrm{CO} 3,2 \%$ SDS, $0.25 \mathrm{mM}$ PMSF, $10 \mathrm{mg} / \mathrm{ml} \mathrm{leu-}$ peptin, $2 \mathrm{mg} / \mathrm{ml}$ aprotinin, $10 \mathrm{mg} / \mathrm{ml}$ pepsin) and then sonicated and centrifuged at $13400 \mathrm{~g}$ for $30 \mathrm{~min}$ utes at $4{ }^{\circ} \mathrm{C}$. The supernatant was used for protein determination by BCA assay and for electrophoresis analysis. Samples (20-50 $\mu \mathrm{g})$ were added to SDS sample loading buffer $2 \times(10 \%$ glycerol, $2 \%$ SDS, $0.1 \%$ bromophenol blue, $50 \mathrm{mM}$ Tris, $\mathrm{pH} 6.8$ and $5 \% \beta$-mercaptoethanol), electrophoresed in $10 \%$ SDSpolyacrylamide gels and then electroblotted to $0.45 \mu \mathrm{m}$ nitrocellulose membranes.

For immunolabeling, the blots were blocked with TTBS solution (20 mM Tris-HCl, pH 7.6, $137 \mathrm{mM}$ $\mathrm{NaCl}$ plus $0.1 \%$ Tween 20 , and $5 \%$ dry skimmed milk) for 2 hours at room temperature. After blocking non-specific binding, the membranes were incubated overnight with specific antibodies in blocking solution at $4{ }^{\circ} \mathrm{C}$. Later, blots were washed twice with blocking solution for 10 minutes followed by another two washes with TTBS for 5 minutes each. The blots were developed by chemiluminiscence detection using a commercial kit (ECL-Amershan Biosciences) and quantified by computer-assisted video densitometry. $\beta$-actin was used as a control of charge. We used the following antibodies: mouse monoclonal antiHSP70 (1:1000), goat polyclonal anti-p62 (SQSTM-1) (1:500), and anti-nitric oxide (NOS2; 1:1000) antibody from Santa Cruz (Temecula, California). Mouse monoclonal anti tau-5 antibody (for measurement of total tau protein) from Chemicon (Madrid, Spain) diluted 1:5000. Rabbit polyclonal to phospho-tau (phospho serine $199+$ serine202) (1:1000) was from Abcam (Cambridge, UK). Mouse monoclonal A $\beta$ antibody 6E10 (Covance), diluted 1:1000. Mouse monoclonal anti-glial fibrillar acid protein (GFAP) antibody diluted 1:5000 was from Chemicon (Madrid, Spain). Mouse anti OX-6 antibody was from SEROTEC (Dusseldorf, Germany; 1/500). Mouse monoclonal antibody against cytochrome $\mathrm{C}$ oxidase (complex IV) subunit I (1:500 to 1:1000) was from Molecular Probes (Invitrogen, Ltd, UK). Rabbit anti-GSK-3 $\alpha$ [pY ${ }^{279}$ ] / $\beta\left[\mathrm{pY}^{216}\right]$ (1:500) was from Invitrogen (Carlsbad, CA, USA). Rabbit polyclonal antibody anti-LC3 (1:1000) was from MBL International Corporation (Hamburg, Germany). Rabbit polyclonal anti-beclin-1 
(1:700) and mouse monoclonal anti- $\beta$-actin antibody diluted 1:10000 were from Sigma. Goat anti-mouseHRP and anti-rabbit-HRP secondary antibodies diluted 1:1000 were from Amersham; donkey anti-goat-HRP was from Santa Cruz (Temecula, California). $\beta$-actin secondary antibody was an anti-mouse phosphatase alkaline conjugated diluted 1:3000 from Sigma.

\section{Statistical analysis}

Prior to statistical analysis, the data were tested, in order to assure that the values come from a Gaussian distribution, with a Kolmogorov-Smirnov test (with Dallal-Wilkinson-Lilliefor $p$ value). Significant differences between the experimental groups were analyzed with Student $t$ test. Differences were considered statistically significant when $p<0.05$.

\section{RESULTS}

Sativex ${ }^{\circledR}$ improves stress and aggressive behavior of $\mathrm{PK}^{-/-} / \mathrm{Tau}^{V L W}$ mice

The amount of food and the volume of water consumed by the $\mathrm{PK}^{-/-} / \mathrm{Tau}^{\mathrm{VLW}}$ mice did not change with Sativex ${ }^{\circledR}$ treatment. The vehicle and Sativex ${ }^{\circledR}$-treated mice maintained the same levels of weight (data not shown).

$\mathrm{PK}^{-/-} / \mathrm{Tau}^{\mathrm{VLW}}$ mice have a reduced stride length, an index of parkinsonian involvement of gait, less distance covered in an open field [25, 27]. Sativex ${ }^{\circledR}$ treatment did not change these parameters (data no shown). However, in comparison with vehicle-treated $\mathrm{PK}^{-/-} / \mathrm{Tau}^{\mathrm{VLW}}$ mice, the treatment with Sativex ${ }^{\circledR}$ showed a significant improvement of abnormal behaviors related to stress, such as auto and hetero-aggressive behavior and stereotypes. Sativex ${ }^{\circledR}$ decreased the marble burying index and increased the percentage of grooming (Fig. 1A-D). There was a significant reduction of self-injury facial masks, which was very severe in vehicle-treated $\mathrm{PK}^{-/-} / \mathrm{Tau}^{\mathrm{VLW}}$ mice and very mild in the Sativex ${ }^{\circledR}$-treated littermates (Fig. 1D).

Effects of Sativex ${ }^{\circledR}$ on monoamine metabolism in $P K^{-/-} / T_{a u}{ }^{V L W}$ mice. Cannabinoids modulate dopamine activity and reduce reactive oxygen species production

The levels of dopamine and its metabolites in the limbic system and striatum are reduced in $\mathrm{PK}^{-/-} / \mathrm{Tau}^{\mathrm{VLW}}$ mice [26]. The treatment of these animals with Sativex ${ }^{\circledR}$ did not change significantly the levels of dopamine but significantly reduced the metabolites of dopamine, 3,4-dihydroxyphenylacetic acid (DOPAC) and homovanillic acid (HVA) in the limbic system (Table 1) and, therefore, the metabolism of dopamine, as represented by the ratio DOPAC/dopamine and HVA/dopamine (Fig. 2A-C). The metabolism of dopamine to DOPAC and HVA is mediated by monoamine oxidase (MAO) and, as such, linked to the production of free radicals with one molecule of $\mathrm{H}_{2} \mathrm{O}_{2}$ for each molecule of dopamine metabolized. The treatment with Sativex ${ }^{\circledR}$ of $\mathrm{PK}^{-/-} / \mathrm{Tau}^{\mathrm{VLW}}$ reduced the production of free radicals linked to dopamine metabolism in dopamine rich areas such as the limbic system and striatum. No significant differences in the levels of other monoamines and metabolites were found in other brain areas, such as the midbrain, with lower concentrations of dopamine.

\section{Effect of Sativex ${ }^{\circledR}$ on the brain redox state of $P K^{-/-} /$Tau$^{V L W}$ mice}

We further investigated the effect of Sativex ${ }^{\circledR}$ on free radicals. One reliable oxidative stress indicator is the level of glutathione, a tri-peptide with antioxidant properties. The levels of reduced GSH were significantly increased in the limbic system of mice treated with Sativex ${ }^{\circledR}$ compared to those treated with vehicle (Table 2). The treatment with Sativex ${ }^{\circledR}$ induced a mild increase in the amount of GSx as well a nonsignificant decrease in the GSSG in the limbic system. The treatment with Sativex ${ }^{\circledR}$ significantly increased the GSH/GSSG ratio, an indirect indicator of the reserve of free radical scavengers. No difference of these parameters was found in striatum or midbrain.

\section{Sativex ${ }^{\circledR}$ reduces gliosis and neuroinflammation in $P K^{-/-} / T_{a u}{ }^{V L W}$ mice}

We used immunofluorescence and western blot analysis to estimate the effect of Sativex ${ }^{\circledR}$ on the expression of inflammatory proteins. The astroglial reactivity, measured as the fluorescence intensity and the area occupied by GFAP ${ }^{+}$cells, was reduced in the hippocampus of $\mathrm{PK}^{-/-/} \mathrm{Tau}^{\mathrm{VLW}}$ mice treated with Sativex ${ }^{\circledR}$ (Fig. 3A). The levels of GFAP were also lower in the cerebral cortex of $\mathrm{PK}^{-/-} / \mathrm{Tau}^{\mathrm{VLW}}$ mice treated with Sativex ${ }^{\circledR}$ than in those treated with vehicle (Fig. 3B).

The activation of microglia was assessed by western blot of OX-6 expression and by immunohistochemistry with anti-Iba 1 antibody. Likewise, in our findings with astroglia, Sativex ${ }^{\circledR}$ reduced the activation of microglia 
A

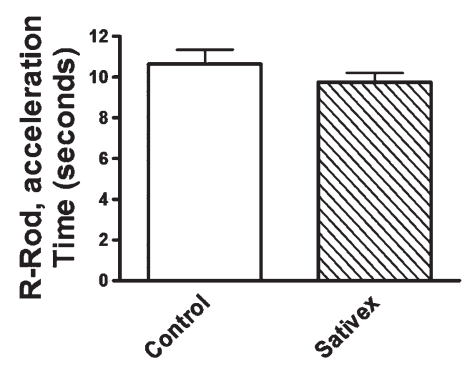

B

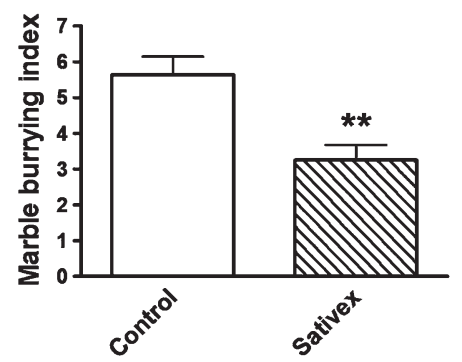

C

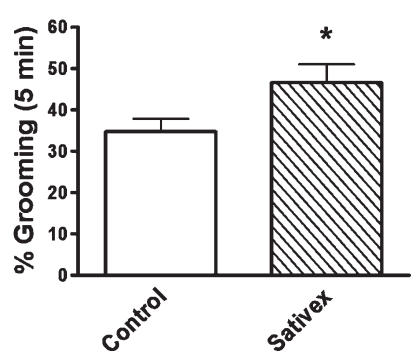

D

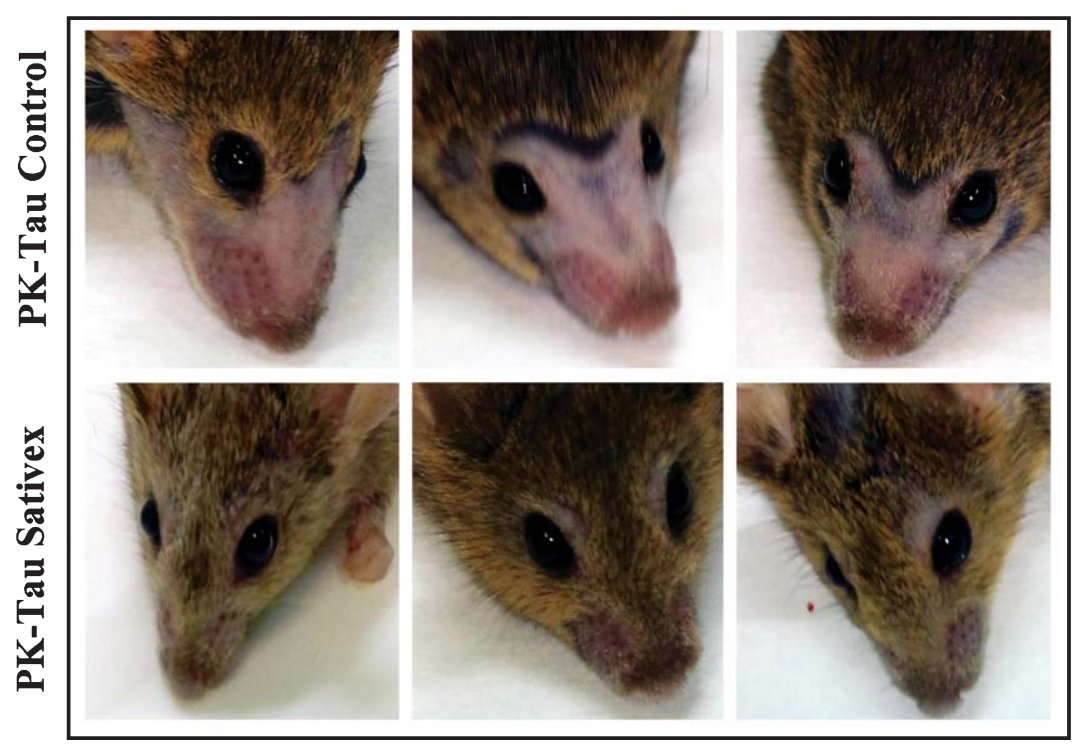

Fig. 1. Study of motor coordination, anxiety, and auto-lesion behavior in $\mathrm{PK}^{-/-} / \mathrm{Tau}^{\mathrm{VLW}}$ treated with cannabinoids. A) Time spent in the barrel of the "Rota-rod" in a program of acceleration as an index of motor coordination. B) Index of marbles buried in the "Marble burying test", considered index of anxiety (score: $1=$ complete marble buried, $0.75=3 / 4$ buried, $0.5=$ half buried, and $0=$ unearthed). C) Percentage of grooming time for 5 minutes, after vaporization of water to initiate behavior of "grooming". Values are expressed as mean $\pm \operatorname{SEM} n=9$ for each experimental group. Statistical analysis performed by Student $t$ test. ${ }^{*} p<0.05,{ }^{*} p<0.01$ PK-Tau treated with Sativex ${ }^{\circledR}$ versus PK-Tau treated with solvent. D) Images of the outcome of the auto-lesion facial PK-Tau behavior in control and treated mice with Sativex ${ }^{\circledR}$. A decrease of the self-injury “masks", related to compulsive behavior in mice treated with Sativex ${ }^{\circledR}$ can be noticed.

Table 1

Monoamine metabolism in brain regions of $\mathrm{PK}^{-/-} / \mathrm{Ttau}^{\mathrm{VLW}}$ mice treated with Sativex ${ }^{\circledR}$ or vehicle for one month

\begin{tabular}{|c|c|c|c|c|c|c|}
\hline \multirow{2}{*}{ Groups } & \multicolumn{2}{|c|}{ Limbic System } & \multicolumn{2}{|c|}{ Striatum } & \multicolumn{2}{|c|}{ Midbrain } \\
\hline & Control & Sativex & Control & Sativex & Control & Sativex \\
\hline Dopamine & $2420 \pm 226$ & $2256 \pm 234$ & $6915 \pm 189$ & $7509 \pm 460$ & $223 \pm 6$ & $237 \pm 12$ \\
\hline 3-MT & $218 \pm 22$ & $165 \pm 7$ & $568 \pm 9$ & $496 \pm 27$ & nd & nd \\
\hline DOPAC & $287 \pm 34$ & $200 \pm 9^{*}$ & $453 \pm 15$ & $407 \pm 23$ & $98 \pm 7$ & $83 \pm 3$ \\
\hline HVA & $314 \pm 27$ & $246 \pm 8^{*}$ & $779 \pm 21$ & $674 \pm 39$ & $137 \pm 117$ & $117 \pm 4$ \\
\hline NA & $685 \pm 37$ & $656 \pm 48$ & $522 \pm 39$ & $508 \pm 22$ & $1473 \pm 36$ & $1488 \pm 59$ \\
\hline 5-HT & $1298 \pm 80$ & $1274 \pm 90$ & $947 \pm 94$ & $910 \pm 89$ & $1972 \pm 63$ & $1983 \pm 48$ \\
\hline 5-HIAA & $346 \pm 23$ & $330 \pm 23$ & $216 \pm 14$ & $190 \pm 16$ & $646 \pm 19$ & $613 \pm 8$ \\
\hline
\end{tabular}

Results are expressed in nanograms per gram of fresh tissue and as percentage of controls. Values are expressed as the mean $\pm \operatorname{SEM}(n=6$ animals in each experimental group). Statistical analysis was performed by Student $t$ test. ${ }^{*} p<0.05$ PK-Tau mice treated with Sativex ${ }^{\circledR}$ versus PK-Tau mice treated with vehicle. 
A
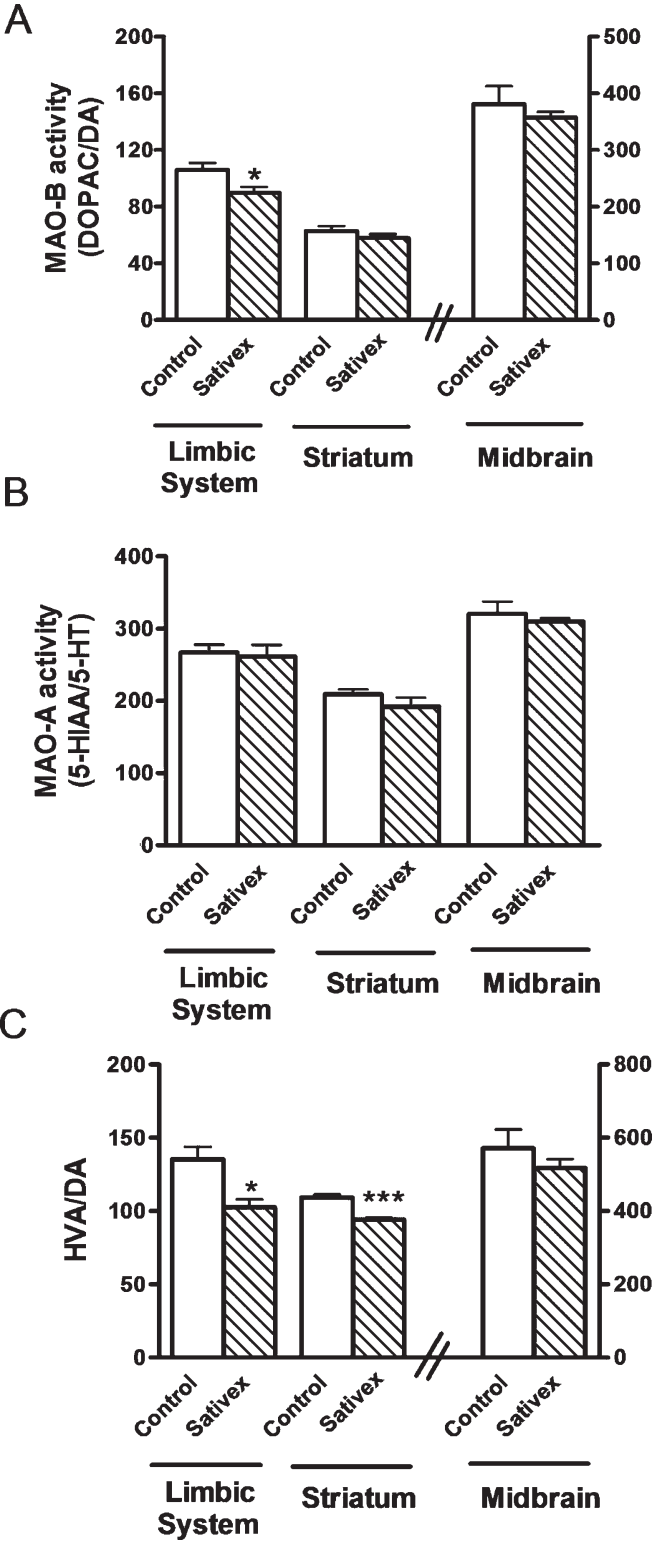

Fig. 2. Cannabinoids modulate dopamine metabolism in dopaminerich regions in $\mathrm{PK}^{-/-} / \mathrm{Tau}^{\mathrm{VLW}}$ mice. MAO-B activity (A), MAO-A activity (B), and HVA/dopamine ratios (C) in limbic system, striatum, and midbrain. Results are expressed in nanograms per gram of fresh tissue. Values are the mean $\pm \operatorname{SEM}(n=6$ mice in each experimental group). Statistical analysis was performed by Student $t$ test. ${ }^{*} p<0.05, * * * p<0.001$ PK-Tau-Sativex ${ }^{\circledR}$ versus PK-Tau-solvent.

in $\mathrm{PK}^{-/-} / \mathrm{Tau}^{\mathrm{VLW}}$ mice in comparison with vehicle (Figs. 3C, 3D, and 3F).

Nitric oxide (NO) is a pro-oxidant generated by the enzyme nitric oxide synthase (NOS), of which there are three related forms: Types I and III NOS are constitutively expressed in cells of neural and endothelial origin, respectively. In contrast, the inducible type II NOS (iNOS) is expressed in cells with immunoregulatory function. To analyze expression of iNOS, western blot analysis was carried out. Sativex ${ }^{\circledR}$, in comparison with the placebo, significantly decreased the iNOS expression in cerebral cortex (Fig. 3E).

\section{Sativex ${ }^{\circledR}$ reduces neuritic plaques and neurofibrillary tangles}

$\mathrm{PK}^{-/-} / \mathrm{Tau}^{\mathrm{VLW}}$ mice develop amyloid pathology and tau pathology [26] (Supplementary Figure 2). In order to determine the effects of Sativex ${ }^{\circledR}$ in tau pathology, we performed immunohistochemical studies in brain sections from $\mathrm{PK}^{-/-} / \mathrm{Tau}^{\mathrm{VLW}}$ mice (4 slices/mice $\times 3$ mice, 12 slices/group), treated with Sativex ${ }^{\circledR}$ or vehicle, with the phospho-specific anti-tau5 antibody. We observed strong anti-tau5 immunostaining in the hippocampus and cerebral cortex of these animals but the number of neuritic plaques and neurofibrillary tangles were significantly reduced in the Sativex ${ }^{\circledR}$ treated mice (Figs. 4A-B).

Next, we assessed changes in tau pathology and in the phosphorylation of proteins using biochemical methods. We performed western blots of tau with antibodies that bind to total tau, and phosphorylated tau at specific residues Ser199 and Ser202. The treatment with Sativex ${ }^{\circledR}$ reduced the levels of phosphorylated tau between 20 and 30\%, in comparison with the vehicle treatment, in the cerebral cortex (Figs. 4C-D) and striatum (Figs. 4F-G). Sativex ${ }^{\circledR}$ also reduced the ratio p-GSK-3/total GSK-3 in comparison with vehicle in $\mathrm{PK}^{-/-} / \mathrm{Tau}^{\mathrm{VLW}}$ (Fig. 4E).

\section{Effect of Sativex ${ }^{\circledR}$ on A $\beta$ pathology: A $\beta$ plaques and oligomers}

To determine the effects of Sativex ${ }^{\circledR}$ on $A \beta$ pathology, we first analyzed whether this treatment altered plaque load in the $\mathrm{PK}^{-/-} / \mathrm{Tau}^{\mathrm{VLW}}$ mice. We stained brain sections from $\mathrm{PK}^{-/-} / \mathrm{Tau}^{\mathrm{VLW}}$, treated with Sativex ${ }^{\circledR}$ or vehicle, with a specific anti-A $\beta_{1-42}$ antibody. A widespread $A \beta$ deposition was observed in different brain areas, including the hippocampus, less pronounced in Sativex ${ }^{\circledR}$ than in vehicle-treated $\mathrm{PK}^{-/-} / \mathrm{Tau}^{\mathrm{VLW}}$ mice (Fig. $5 \mathrm{~A}$ ). The number of $\mathrm{A} \beta$ plaques in cortex and hippocampus of $\mathrm{PK}^{-/-} / \mathrm{Tau}^{\mathrm{VLW}}$ mice was reduced in the Sativex ${ }^{\circledR}$ by $42 \%$ and $70 \%$, respectively, in comparison with those treated with vehicle (Fig. 5B).

We measured the effect of Sativex ${ }^{\circledR}$ on $A \beta$ oligomer levels by western blot analysis of cerebral cortex. 
Table 2

Effects of Sativex ${ }^{\circledR}$ on glutathione homeostasis in brain regions of parkin ${ }^{-/-} /$tau $^{\mathrm{VLW}}$ mice treated with Sativex ${ }^{\circledR}$ or vehicle for one month

\begin{tabular}{|c|c|c|c|c|c|c|}
\hline & \multicolumn{2}{|c|}{ Limbic System } & \multicolumn{2}{|c|}{ Striatum } & \multicolumn{2}{|c|}{ Midbrain } \\
\hline & Control & Sativex & Control & Sativex & Control & Sativex \\
\hline$\overline{G S x}$ & $430 \pm 14$ & $480 \pm 16^{*}$ & $587 \pm 30$ & $589 \pm 27$ & $865 \pm 48$ & $853 \pm 51$ \\
\hline GSH & $416 \pm 14$ & $468 \pm 16^{*}$ & $568 \pm 29$ & $568 \pm 28$ & $837 \pm 51$ & $825 \pm 58$ \\
\hline GSSG & $14 \pm 0.5$ & $12 \pm 0.6$ & $19 \pm 0.4$ & $21 \pm 0.9$ & $28 \pm 1.4$ & $28 \pm 0.8$ \\
\hline GSH/GSSG & $30 \pm 1.9$ & $39 \pm 1.9 * *$ & $30 \pm 2.3$ & $27 \pm 1.1$ & $30 \pm 1.2$ & $29 \pm 1.1$ \\
\hline
\end{tabular}

Total glutathione (GSx), reduced (GSH), and oxidized (GSSG) glutathione levels expressed in microgram per gram of tissue. Values are the mean \pm SEM ( $n=6$ animals in each experimental group). Statistical analysis was performed by Student $t$ test. ${ }^{*} p<0.05, * * p<0.01$ PK-Tau mice treated with Sativex ${ }^{\circledR}$ versus PK-Tau mice treated with vehicle.
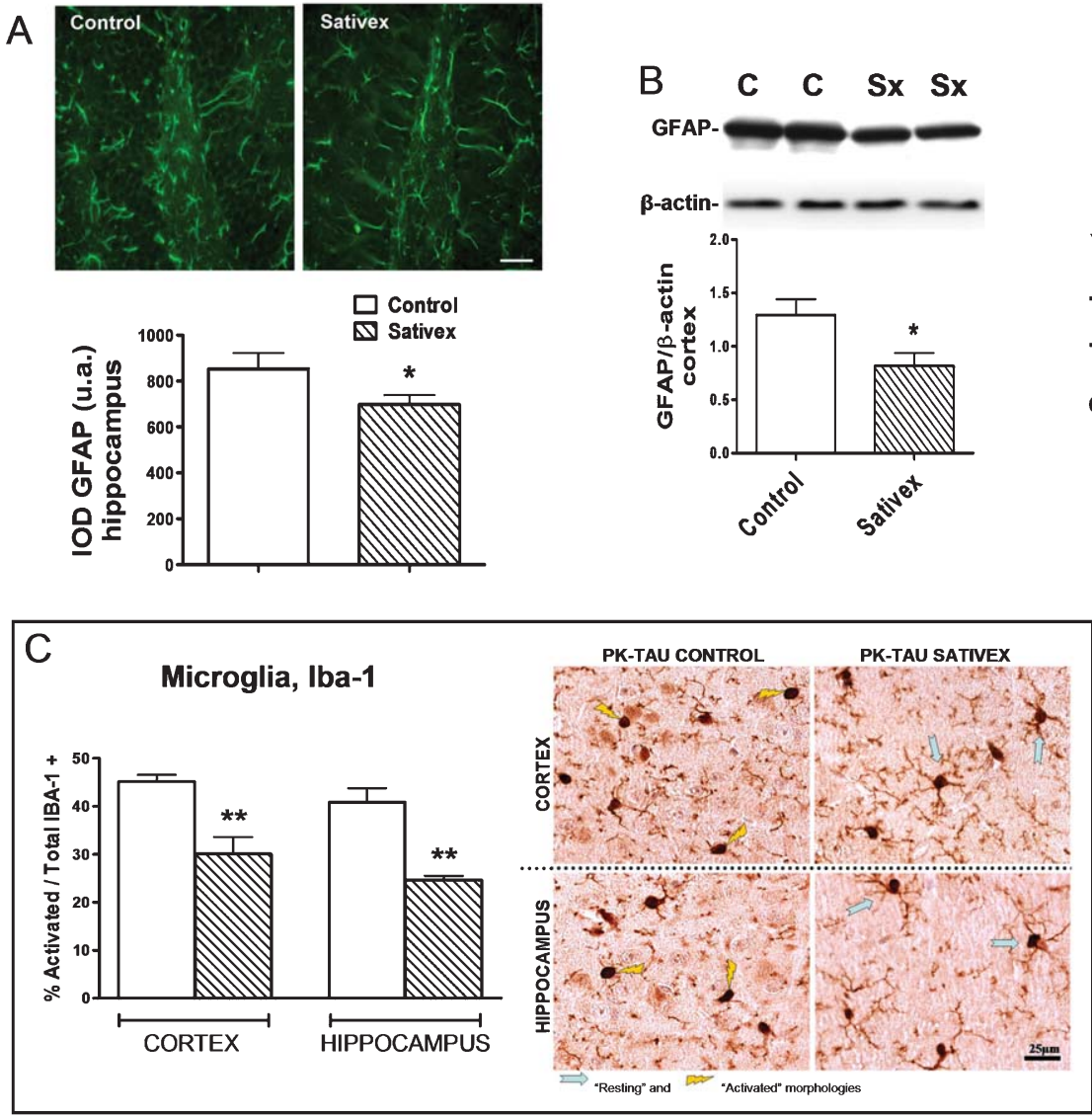



Limbic System

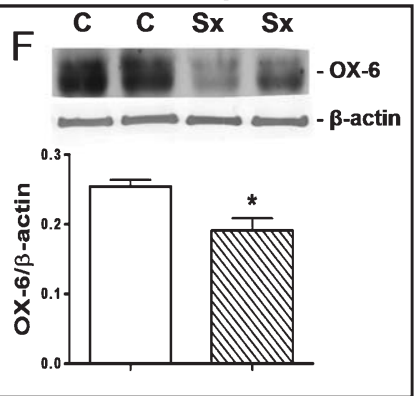

Fig. 3. Glial markers and iNOS expression are decreased in cannabinoid-treated $\mathrm{PK}^{-/-} / \mathrm{Tau}^{\mathrm{VLW}}$ mice. A) Representative microphotographs showing GFAP hippocampus immunoreactive $($ scale bar $=30 \mu \mathrm{m})$ and the $\mathrm{GFAP}^{+}$fluorescence area quantification $(20$ fields at $20 \times$ of $9-12$ slices along hippocampus of 3 mice). B) Representative western blot of GFAP and the densitometric histogram in cortex $(n=6$ mice). C) The number and morphology of microglia cells were assessed by Iba1 staining in hippocampus and cerebral cortex. D) Activated microglia (OX-6) proteins $\left(n=6\right.$ mice) and (E) effects of Sative ${ }^{\circledR}$ on iNOS protein expression with their respective densitometric histogram in cortex $(n=6$ mice). F) Effects of Sativex ${ }^{\circledR}$ on activated microglia (OX-6) protein expression in limbic system. $\beta$-actin was used as charge control. Values are the mean $\pm \operatorname{SEM}(n=6)$. Statistical analysis was performed by Student $t$ test. ${ }^{*} p<0.05,{ }^{*} p<0.01,{ }^{* * *} p<0.001$, Sativex ${ }^{\circledR}$-treated mice versus control. 
Tau pathology

A Neuritic plaques, Hippocampus

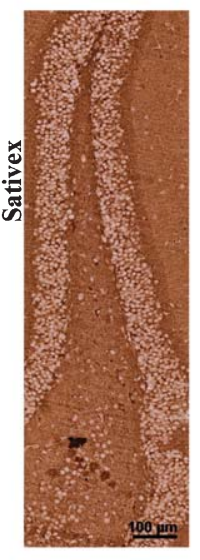

Neurofibrillary tangles, Cerebral Cortex

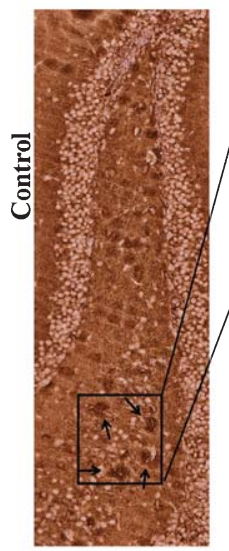

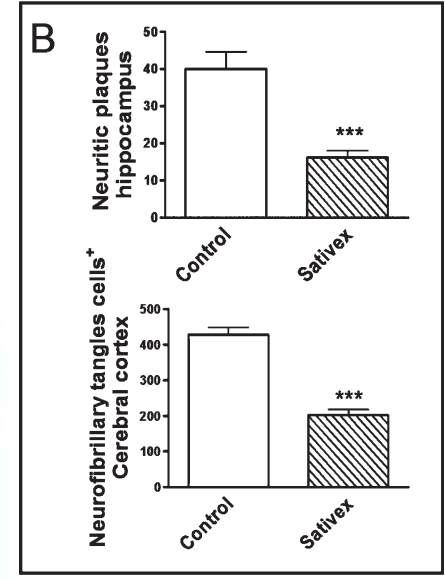

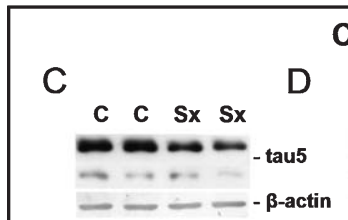

\section{Cerebral cortex}

c c sx Sx $\quad$ c c sx sx
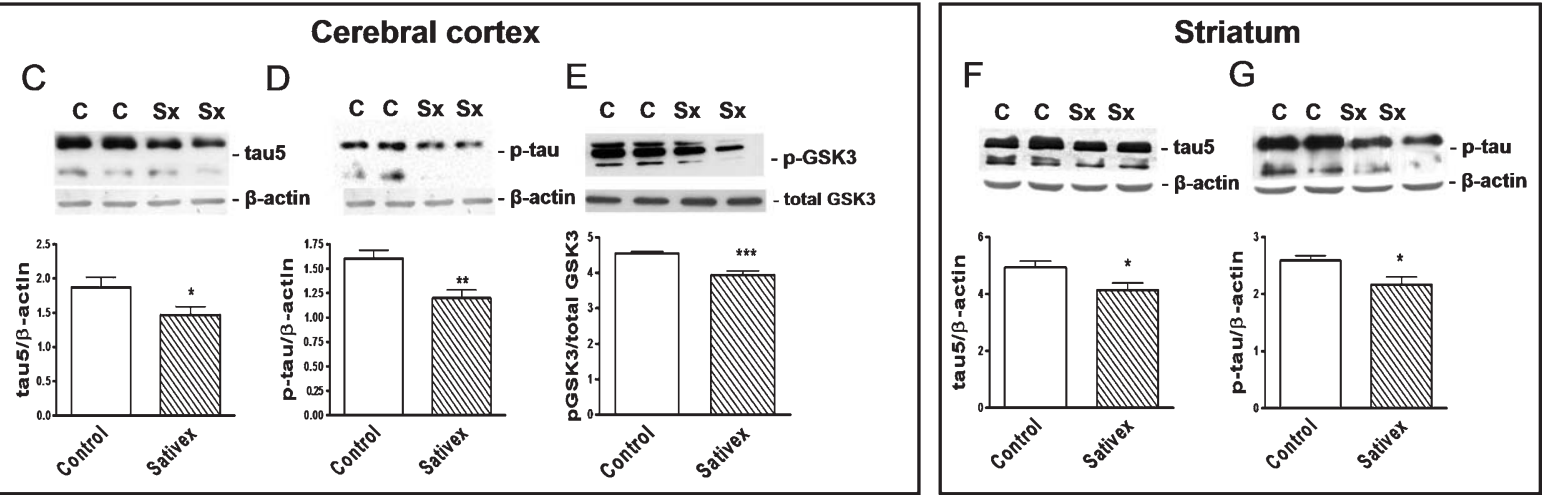

Fig. 4. Cannabinoid treatment decreases tau pathology in $\mathrm{PK}^{-/-} / \mathrm{Tau}^{\mathrm{VLW}}$ mice. A) Representative microphotograph of the hippocampus (scale bar $=100 \mu \mathrm{m}$ ) and cortex (scale bar $=30 \mu \mathrm{m}$ ), immunostained with tau-5 antibody. A portion of this micrograph has been magnified in the picture on the right. B) Quantification of neuritic plaques in hippocampus and cells with neurofibrillary tangles in cortex (number of neuritic plaques/slices), expressed as the mean \pm SEM (9-12 slices/group of 3 mice). Representative western blot and densitometric analysis of total tau levels with anti-tau-5 (C), phosphorylated tau (phospho S199+S202) (D) and representative western blot of GSK-3a [pY279]/b [pY216]/total GSK3 in cortex (E). Representative western blot of total tau levels (F) and phosphorylated tau (phospho S199+S202) (G) in the striatum. The values are expressed as the mean $\pm \operatorname{SEM}(n=6$ mice in each experimental group). Statistical analysis was performed by Student $t$ test. * $p<0.05$, $* * p<0.01, * * * p<0.001$ Sativex ${ }^{\circledR}$-treated mice versus control.

The treatment with Sativex ${ }^{\circledR}$ reduced the levels of $\mathrm{A} \beta$ oligomers in $\mathrm{PK}^{-/-} / \mathrm{Tau}^{\mathrm{VLW}}$, in comparison with vehicle-treated animals (Figs. 5C-D).

Effects of Sativex ${ }^{\circledR}$ on the expression of chaperone Hsp-70 protein, mitochondrial function, and autophagy markers

The levels of Hsp-70, a chaperone protein that increases in situations of stress, were significantly lower in $\mathrm{PK}^{-/-} / \mathrm{Tau}^{\mathrm{VLW}}$ mice treated with Sativex ${ }^{\circledR}$ than in those treated with vehicle (Fig. 6A)

Cytochrome $c$ oxidase subunit IV (Complex IV) is a mitochondrial protein and an index of energy production. Western blots obtained from lysates from the cerebral cortex of $\mathrm{PK}^{-/-} / \mathrm{Tau}^{\mathrm{VLW}}$ mice showed higher levels of this Complex IV protein in Sativex ${ }^{\circledR}$ than in vehicle-treated mice (Fig. 6B), so suggesting a higher metabolic activity.

The SQSTM1/p62 protein (hereafter referred to as p62), an endogenous autophagy substrate, is widely used to monitor the activation of autophagy. P62 has an ubiquitin-associated domain which is capable of interacting with ubiquitinated proteins and a LC3interacting region and with LC3. In addition, p62 can transport ubiquitinated protein targets to autophagosomes that are destined for degradation. The amount of endogenous p62 protein was found to be lower in Sativex ${ }^{\circledR}$ than in vehicle-treated $\mathrm{PK}^{-/-} / \mathrm{Tau}^{\mathrm{VLW}}$ mice (Fig. 6C), indicating that Sativex ${ }^{\circledR}$ activates the 


\section{Amyloid pathology}
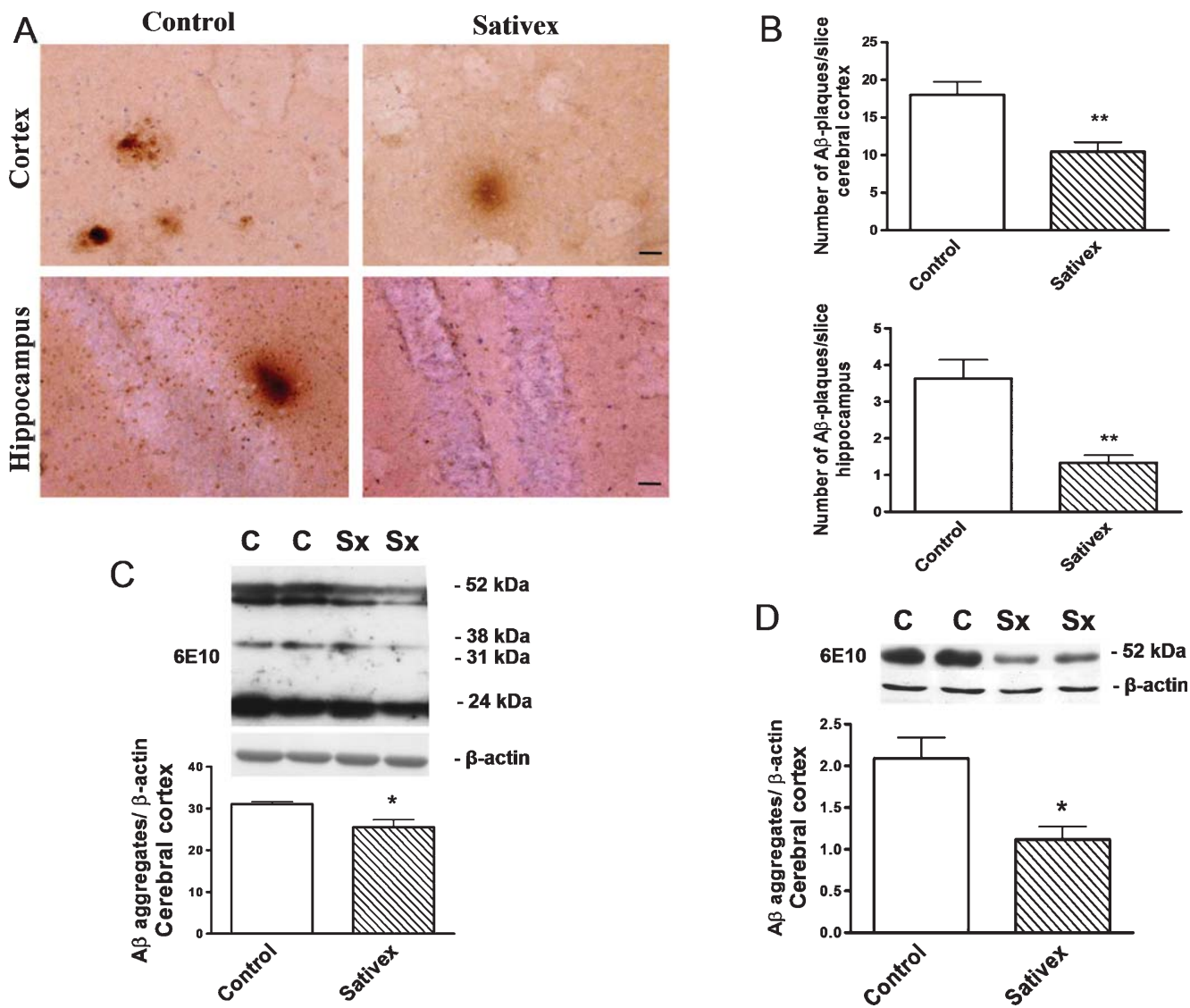

Fig. 5. Cannabinoids reduce $A \beta$ accumulation and aggregation in treated $\mathrm{PK}^{-/-} / \mathrm{Tau}^{\mathrm{VLW}}$ mice. A) Representative microphotographs of cortex and hippocampus immunostained with $A \beta_{1-42}$ antibody (scale $b a r=30 \mu \mathrm{m}$ ). B) The number of $A \beta$ inclusions per slice was quantificated as the mean \pm SEM (12 slices in each experimental group with 4 brain section per mice, $n=3$ mice). C) Image of $\mathrm{A} \beta$ aggregates by western blot with anti-amyloid- $\beta$ (6E10). D) Quantification of $52 \mathrm{KDa} A \beta$ aggregates. Values are the mean $\pm \operatorname{SEM}(n=6$ mice in each experimental group), repeated twice. Statistical analysis was performed by Student $t$ test. ${ }^{*} p<0.05,{ }^{*} p<0.01$ Sativex ${ }^{\circledR}$-treated mice versus control.

autophagic degradation pathway. In addition, other changes in the expression of components related to the autophagy pathway were monitored. Immunoblot assays revealed that Sativex ${ }^{\circledR}$ increased the turnover of LC3-I to LC3-II, a phosphatidylethanolamineconjugated form of microtubule-associated protein 1 light chain 3 (LC3), as compared with vehicle control-treated mice (Fig. 6D), indicating that Sativex ${ }^{\circledR}$ induced autophagy in $\mathrm{PK}^{-/-} / \mathrm{Tau}^{\mathrm{VLW}}$ mice. Beclin-1 is a component of the class III PI3 kinase complex and is required for autophagy initiation by various stimuli, such as nutrient starvation, hypoxia, growth factor withdrawal, and rapamycin treatment. The level of beclin-1 was markedly increased in Sativex ${ }^{\circledR}$ $\mathrm{PK}^{-/-} / \mathrm{Tau}^{\mathrm{VLW}}$ treated mice (Fig. 6E).

These results suggest that Sativex ${ }^{\circledR}$ reduces the tau and amyloid pathology in $\mathrm{PK}^{-/-} / \mathrm{Tau}^{\mathrm{VLW}}$ brain through reduction of free radicals, enhancement of mitochondrial activity, and stimulation of autophagy.

\section{DISCUSSION}

We have used $\mathrm{PK}^{-/-} / \mathrm{Tau}^{\mathrm{VLW}}$ mice, as a model of complex neurodegenerative disorders, to test the neuroprotective effects of Sativex ${ }^{\circledR}$, a cannabinoidbased medicine already approved for clinical use, in complex neurological conditions. $\mathrm{PK}^{-/-} / \mathrm{Tau}^{\mathrm{VLW}}$ mice display clinical features and pathological lesions similar to those observed in patients with frontotemporal dementia, parkinsonism, and lower motor neuron deficits; a syndrome that could be due to hereditary tauopathies as well as to mutations of other genes such as progranulin, TDP-43, and FUS [39]. In this animal model of multi systemic neurological disorders, we 
A

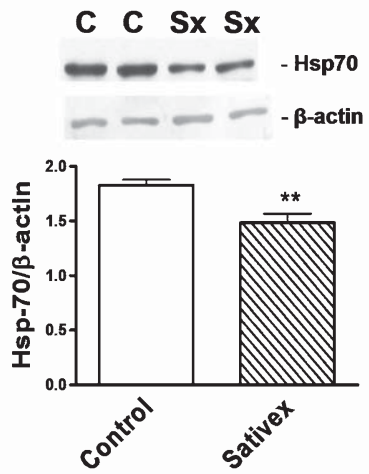

B

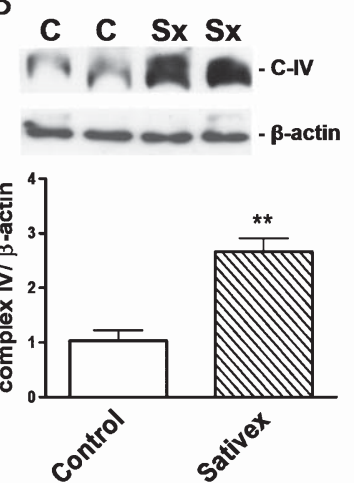

C

c c sx $5 x$
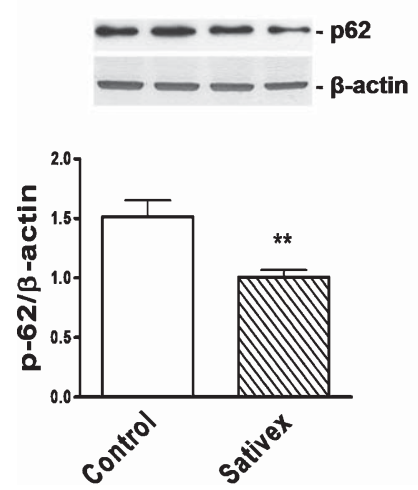

D

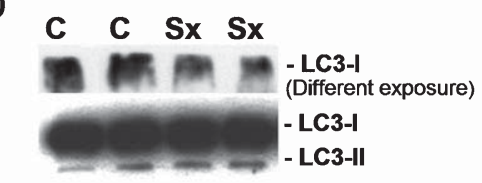

E

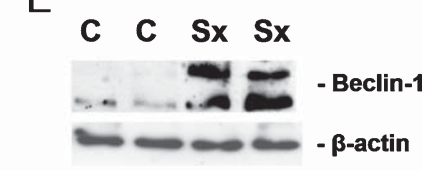

Fig. 6. Autophagy and reactive oxygen species related mechanisms of cannabinoid effects on PK ${ }^{-/-} / \mathrm{Tau}^{\mathrm{VLW}}$ mice pathology. HSP-70 (A), Complex IV (B), P62 (C), and LC3II/I (D) ratios and Beclin protein expression (E). $\beta$-actin was used as charge control. Data are expressed as the mean $\pm \operatorname{SEM}\left(n=6\right.$ mice in each experimental group). Statistical analysis was performed by Student $t$ test. $* * p<0.01$ Sativex ${ }^{\circledR}$-treated mice versus control.

have observed that Sativex ${ }^{\circledR}$ improves behavioral features, dopamine metabolism, oxidative stress, and glial function as well as tau and amyloid pathology. Behavior features improved by Sativex ${ }^{\circledR}$ were those mostly related with anxiety, such as self-injure behavior and facial masking, symptoms of involvement of the limbic system, which is one of the areas most severely involved in frontotemporal dementias. These effects are in agreement with the known role of cannabinoids in modulating emotional and non-emotional memory processes in the hippocampus [40]. In addition, the role of cannabinoids in mood and anxiety disorders has been described [34-36].

We also observed that these behavioral changes are associated with a reduction in dopamine metabolism, most importantly in the limbic area. Treatment with Sativex ${ }^{\circledR}$ also improved the oxidative stress observed in the $\mathrm{PK}^{-/-} / \mathrm{Tau}^{\mathrm{VLW}}$ mice; the levels of proteins involved in mitochondrial energy production and normalized the levels of chaperones. Sativex ${ }^{\circledR}$ reduced astroglial and microglial activation. These effects could be mediated in part through CB2 receptors [9-11, $41,42]$ and also through the improvement of the redox state. Free radical donors, including NO, compounds that were reduced by treatment with Sativex ${ }^{\circledR}$, are known to activate glia [43].

Several mechanisms of action could explain the effects of Sativex ${ }^{\circledR}$ on $\mathrm{PK}^{-/-} / \mathrm{Tau}^{\mathrm{VLW}}$ mice. Cannabinoids modulate dopamine activity, an effect mediated by CB1 receptors [44]. In addition, cannabinoids directly inhibit MAO activity in the mitochondria [45], in a receptor independent function. This inhibition of mitochondrial MAO could reduce free radical production by mitochondria and improve mitochondrial function.

Sativex ${ }^{\circledR}$ had an impressive effect on tau and $A \beta$ pathology in $\mathrm{PK}^{-/-} / \mathrm{Tau}^{\mathrm{VLW}}$ mice. The mechanisms of this effect appear to be related with potentiation of autophagy, without excluding other possibilities, such as improvement of the redox state. Excess tau, which 
is present in some human fronto-temporal dementias and in $\mathrm{PK}^{-/-} / \mathrm{Tau}^{\mathrm{VLW}}$ mice, blocks the intracellular traffic of organelles, diminishes axonal transport, and impairs microtubule dynamics [46-49]. Autophagic vesicles accumulate in large numbers when fusion of autophagosomes with lysosomes is slowed by disrupting their transport in microtubules with vinblastine or nocodazole [50, 51]. Therefore, mutated tau overexpression may impair autophagy affecting microtubular transport of autophagic vesicles. Parkin suppression alters tau aggregation, degradation, and solubility in the brain of aged mice [38]. Parkin is protective for nigro-striatal dopamine neurons in a tau gene transfer neurodegenerative model [52]. Not surprisingly, parkin also protects dopamine neurons against microtubule-depolymerizing toxins [53]. Parkin and tau interaction has been described after overexpression of both proteins [54]. The protective effects of Sativex ${ }^{\circledR}$ on amyloid and tau pathology in $\mathrm{PK}^{-/-} / \mathrm{Tau}^{\mathrm{VLW}}$ mice may be mediated, at least partially, by autophagy induction. Sativex ${ }^{\circledR}$ increased LC3-II levels and beclin expression. On the other hand, Sativex ${ }^{\circledR}$ decreased p62 levels in cerebral cortex. In addition, we have shown decreased levels of tau and p-tau in different brain regions. This indicates that Sativex ${ }^{\circledR}$ not only affects autophagy induction, but could also improve the process of autophagosome-lysosome fusion or the lysosomal degradative activity.

Tau ubiquitination, however, takes place with the complex CHIP-HSP70, but not with parkin [54-56]. Therefore, the protective effects of parkin on tau pathology would most likely be mediated by autophagy rather than by the ubiquitin-proteasome system. In fact, in primary neuronal cultures, the increment in tau and p62 levels after proteasome inhibition with epoxomicin is prevented in parkin-null cultures by compensatory stimulation of autophagic activity. The greater resistance of parkin null cultures to mild proteasome inhibition is eliminated by inhibition of autophagy [57].

In conclusion, Sativex ${ }^{\circledR}$ has significant neuroprotective effects in this complex model of neurodegeneration, thereby making it a promising therapeutic agent in multi-systemic neurological disorders.

\section{ACKNOWLEDGMENTS}

This study has been supported in part by grants from the Spanish Ministry of Health, FIS 2010/172, CIBER 2006/05/0059, CIBERNED PI 2010/ 06, CAM 2011/BMD-2308, SAF2009-04803 and GW Pharma
Ltd, London, UK. JP and MFS have a CIBERNED postdoctoral and a FIS predoctoral fellowship, respectively. The authors thank M. Paz Muñoz for excellent technical assistance, and Ms. Claire Marsden for editorial help.

Authors' disclosures available online (http://www.jalz.com/disclosures/view.php?id=1668).

\section{REFERENCES}

[1] Blazquez C, Chiarlone A, Sagredo O, Aguado T, Pazos MR, Resel E, Palazuelos J, Julien B, Salazar M, Borner C, Benito C, Carrasco C, Diez-Zaera M, Paoletti P, Diaz-Hernandez M, Ruiz C, Sendtner M, Lucas JJ, de Yebenes JG, Marsicano G, Monory K, Lutz B, Romero J, Alberch J, Gines S, Kraus J, Fernandez-Ruiz J, Galve-Roperh I, Guzman M (2011) Loss of striatal type 1 cannabinoid receptors is a key pathogenic factor in Huntington's disease. Brain 134, 119-136.

[2] Chen B, Bromley-Brits K, He G, Cai F, Zhang X, Song W (2010) Effect of synthetic cannabinoid HU210 on memory deficits and neuropathology in Alzheimer's disease mouse model. Curr Alzheimer Res 7, 255-261.

[3] Fernandez-Ruiz J, Hernandez M, Ramos JA (2010) Cannabinoid-dopamine interaction in the pathophysiology and treatment of CNS disorders. CNS Neurosci Ther 16, e72e91.

[4] Fernandez-Ruiz J, Moreno-Martet M, Rodriguez-Cueto C, Palomo-Garo C, Gomez-Canas M, Valdeolivas S, Guaza C, Romero J, Guzman M, Mechoulam R, Ramos JA (2011) Prospects for cannabinoid therapies in basal ganglia disorders. Br J Pharmacol 163, 1365-1378.

[5] Kalifa S, Polston EK, Allard JS, Manaye KF (2010) Distribution patterns of cannabinoid CB1 receptors in the hippocampus of APPswe/PS1DeltaE9 double transgenic mice. Brain Res 1376, 94-100.

[6] Koppel J, Bradshaw H, Goldberg TE, Khalili H, Marambaud P, Walker MJ, Pazos M, Gordon ML, Christen E, Davies P (2009) Endocannabinoids in Alzheimer's disease and their impact on normative cognitive performance: A case-control and cohort study. Lipids Health Dis $\mathbf{8}, 2$.

[7] Koppel J, Davies P (2008) Targeting the endocannabinoid system in Alzheimer's disease. J Alzheimers Dis 15, 495-504.

[8] Krishnan S, Cairns R, Howard R (2009) Cannabinoids for the treatment of dementia. Cochrane Database Syst Rev, CD007204.

[9] Lee JH, Agacinski G, Williams JH, Wilcock GK, Esiri MM, Francis PT, Wong PT, Chen CP, Lai MK (2010) Intact cannabinoid CB1 receptors in the Alzheimer's disease cortex. Neurochem Int 57, 985-989.

[10] Martin-Moreno AM, Reigada D, Ramirez BG, Mechoulam $\mathrm{R}$, Innamorato $\mathrm{N}$, Cuadrado A, de Ceballos ML (2011) Cannabidiol and other cannabinoids reduce microglial activation in vitro and in vivo: Relevance to Alzheimer's disease. Mol Pharmacol 79, 964-973.

[11] Noonan J, Tanveer R, Klompas A, Gowran A, McKiernan J, Campbell VA (2010) Endocannabinoids prevent beta-amyloid-mediated lysosomal destabilization in cultured neurons. J Biol Chem 285, 38543-38554.

[12] Marco EM, Laviola G (2011) The endocannabinoid system in the regulation of emotions throughout lifespan: A discussion on therapeutic perspectives. J Psychopharmacol 26, 150-163. 
[13] Pazos MR, Nunez E, Benito C, Tolon RM, Romero J (2004) Role of the endocannabinoid system in Alzheimer's disease: New perspectives. Life Sci 75, 1907-1915.

[14] Ramirez BG, Blazquez C, Gomez del Pulgar T, Guzman M, de Ceballos ML (2005) Prevention of Alzheimer's disease pathology by cannabinoids: Neuroprotection mediated by blockade of microglial activation. J Neurosci 25, 19041913.

[15] Ruiz-Valdepenas L, Benito C, Tolon RM, Martinez Orgado JA, Romero J (2010) The endocannabinoid system and amyloid-related diseases. Exp Neurol 224, 66-73.

[16] Ruiz-Valdepenas L, Martinez-Orgado JA, Benito C, Millan A, Tolon RM, Romero J (2011) Cannabidiol reduces lipopolysaccharide-induced vascular changes and inflammation in the mouse brain: An intravital microscopy study. $J$ Neuroinflammation $\mathbf{8}, 5$.

[17] Sagredo O, Pazos MR, Satta V, Ramos JA, Pertwee RG, Fernandez-Ruiz J (2011) Neuroprotective effects of phytocannabinoid-based medicines in experimental models of Huntington's disease. J Neurosci Res 89, 1509-1518.

[18] Tolon RM, Nunez E, Pazos MR, Benito C, Castillo AI, Martinez-Orgado JA, Romero J (2009) The activation of cannabinoid CB2 receptors stimulates in situ and in vitro betaamyloid removal by human macrophages. Brain Res $\mathbf{1 2 8 3}$, 148-154.

[19] Palazuelos J, Ortega Z, Diaz-Alonso J, Guzman M, GalveRoperh I (2012) CB2 cannabinoid receptors promote neural progenitor cell proliferation via mTORC1 signaling. J Biol Chem 287, 1198-1209.

[20] Anavi-Goffer S, Baillie G, Irving AJ, Gertsch J, Greig IR, Pertwee RG, Ross RA (2012) Modulation of L-alphalysophosphatidylinositol/GPR55 mitogen-activated protein kinase (MAPK) signaling by cannabinoids. J Biol Chem 287, 91-104.

[21] Giuliano M, Pellerito O, Portanova P, Calvaruso G, Santulli A, De Blasio A, Vento R, Tesoriere G (2009) Apoptosis induced in HepG2 cells by the synthetic cannabinoid WIN: Involvement of the transcription factor PPARgamma. Biochimie 91, 457-465.

[22] Novotna A, Mares J, Ratcliffe S, Novakova I, Vachova M, Zapletalova O, Gasperini C, Pozzilli C, Cefaro L, Comi G, Rossi P, Ambler Z, Stelmasiak Z, Erdmann A, Montalban X, Klimek A, Davies P (2011) A randomized, double-blind, placebo-controlled, parallel-group, enriched-design study of nabiximols* $\left(\right.$ Sativex $\left.{ }^{\circledR}\right)$, as add-on therapy, in subjects with refractory spasticity caused by multiple sclerosis. Eur J Neurol 18, 1122-1131.

[23] Collin C, Davies P, Mutiboko IK, Ratcliffe S (2007) Randomized controlled trial of cannabis-based medicine in spasticity caused by multiple sclerosis. Eur J Neurol 14, 290-296.

[24] Garcia-Arencibia M, Gonzalez S, de Lago E, Ramos JA, Mechoulam R, Fernandez-Ruiz J (2007) Evaluation of the neuroprotective effect of cannabinoids in a rat model of Parkinson's disease: Importance of antioxidant and cannabinoid receptor-independent properties. Brain Res 1134, 162-170.

[25] Rodriguez-Navarro JA, Gomez A, Rodal I, Perucho J, Martinez A, Furio V, Ampuero I, Casarejos MJ, Solano RM, de Yebenes JG, Mena MA (2008) Parkin deletion causes cerebral and systemic amyloidosis in human mutated tau overexpressing mice. Hum Mol Genet 17, 3128-3143.

[26] Menendez J, Rodriguez-Navarro JA, Solano RM, Casarejos MJ, Rodal I, Guerrero R, Sanchez MP, Avila J, Mena MA, de Yebenes JG (2006) Suppression of Parkin enhances nigrostriatal and motor neuron lesion in mice over-expressing human-mutated tau protein. Hum Mol Genet 15, 2045-2058.
[27] Rodriguez-Navarro JA, Rodriguez L, Casarejos MJ, Solano RM, Gomez A, Perucho J, Cuervo AM, Garcia de Yebenes J, Mena MA (2010) Trehalose ameliorates dopaminergic and tau pathology in parkin deleted/tau overexpressing mice through autophagy activation. Neurobiol Dis 39, 423-438.

[28] Mena MA, Rodriguez-Navarro JA, de Yebenes JG (2009) The multiple mechanisms of amyloid deposition: The role of parkin. Prion 3, 5-11.

[29] Garcia-Arencibia M, Garcia C, Kurz A, Rodriguez-Navarro JA, Gispert-Sachez S, Mena MA, Auburger G, de Yebenes JG, Fernandez-Ruiz J (2009) Cannabinoid CB1 receptors are early downregulated followed by a further upregulation in the basal ganglia of mice with deletion of specific park genes. $J$ Neural Transm Suppl 269-275.

[30] Hilliard A, Stott C, Wright S, Guy G, Pryce G, Al-Izki S, Bolton C, Giovannoni G (2012) Evaluation of the efects of Sativex (THC BDS: CBD BDS) on Inhibition of spasticity in a chronic relapsing experimental allergic autoimmune encephalomyelitis: A model of multiple sclerosis. ISRN Neurol 2012, 802649 .

[31] Fentress JC (1988) Expressive contexts, fine structure, and central mediation of rodent grooming. Ann N Y Acad Sci $\mathbf{5 2 5}$, 18-26.

[32] van den Broek FA, Omtzigt CM, Beynen AC (1993) Whisker trimming behaviour in $\mathrm{A} 2 \mathrm{G}$ mice is not prevented by offering means of withdrawal from it. Lab Anim 27, 270272.

[33] Sarna JR, Dyck RH, Whishaw IQ (2000) The Dalila effect: C57BL6 mice barber whiskers by plucking. Behav Brain Res 108, 39-45.

[34] Biala G, Kruk M, Budzynska B (2009) Effects of the cannabinoid receptor ligands on anxiety-related effects of damphetamine and nicotine in the mouse elevated plus maze test. J Physiol Pharmacol 60, 113-122.

[35] Rey AA, Purrio M, Viveros MP, Lutz B (2012) Biphasic effects of cannabinoids in anxiety responses: $\mathrm{CB} 1$ and $\mathrm{GABA}(\mathrm{B})$ receptors in the balance of GABAergic and glutamatergic neurotransmission. Neuropsychopharmacology 37, 2624-2634.

[36] Witkin JM, Tzavara ET, Nomikos GG (2005) A role for cannabinoid CB1 receptors in mood and anxiety disorders. Behav Pharmacol 16, 315-331.

[37] Tietze F (1969) Enzymatic method for quantitative determination of nanogram amounts of total and oxidized glutathione: Application to mammalian blood and other tissue. Anal Biochem 27, 502-522.

[38] Rodriguez-Navarro JA, Casarejos MJ, Menendez J, Solano RM, Rodal I, Gomez A, Yebenes JG, Mena MA (2007) Mortality, oxidative stress and tau accumulation during ageing in parkin null mice. J Neurochem 103, 98-114.

[39] Premi E, Padovani A, Borroni B (2012) Frontotemporal Lobar Degeneration. Adv Exp Med Biol 724, 114-127.

[40] Akirav I (2011) The role of cannabinoids in modulating emotional and non-emotional memory processes in the hippocampus. Front Behav Neurosci 5, 34.

[41] Benito C, Tolon RM, Pazos MR, Nunez E, Castillo AI, Romero J (2008) Cannabinoid CB2 receptors in human brain inflammation. Br J Pharmacol 153, 277-285.

[42] Ehrhart J, Obregon D, Mori T, Hou H, Sun N, Bai Y, Klein T, Fernandez F, Tan J, Shytle RD (2005) Stimulation of cannabinoid receptor 2 (CB2) suppresses microglial activation. $J$ Neuroinflammation 2, 29.

[43] Canals S, Casarejos MJ, de Bernardo S, Solano RM, Mena MA (2003) Selective and persistent activation of extracellular signal-regulated protein kinase by nitric oxide in glial 
cells induces neuronal degeneration in glutathione-depleted midbrain cultures. Mol Cell Neurosci 24, 1012-1026.

[44] Bosier B, Muccioli GG, Mertens B, Sarre S, Michotte Y, Lambert DM, Hermans E (2012) Differential modulations of striatal tyrosine hydroxylase and dopamine metabolism by cannabinoid agonists as evidence for functional selectivity in vivo. Neuropharmacology 62, 2327-2335.

[45] Fisar Z (2010) Inhibition of monoamine oxidase activity by cannabinoids. Naunyn Schmiedebergs Arch Pharmacol $\mathbf{3 8 1}$ 563-572.

[46] Liu B, Hong JS (2003) Role of microglia in inflammationmediated neurodegenerative diseases: Mechanisms and strategies for therapeutic intervention. J Pharmacol Exp Ther 304, 1-7.

[47] Stamer K, Vogel R, Thies E, Mandelkow E, Mandelkow EM (2002) Tau blocks traffic of organelles, neurofilaments, and APP vesicles in neurons and enhances oxidative stress. J Cell Biol 156, 1051-1063.

[48] Stoothoff W, Jones PB, Spires-Jones TL, Joyner D, Chhabra E, Bercury K, Fan Z, Xie H, Bacskai B, Edd J, Irimia D, Hyman BT (2009) Differential effect of three-repeat and fourrepeat tau on mitochondrial axonal transport. J Neurochem 111, 417-427.

[49] Zhang Y, Champagne N, Beitel LK, Goodyer CG, Trifiro M, LeBlanc A (2004) Estrogen and androgen protection of human neurons against intracellular amyloid beta1-42 toxicity through heat shock protein 70. J Neurosci 24, 5315-5321.

[50] Boland B, Kumar A, Lee S, Platt FM, Wegiel J, Yu WH Nixon RA (2008) Autophagy induction and autophagosome clearance in neurons: Relationship to autophagic pathology in Alzheimer's disease. J Neurosci 28, 6926-6937.

[51] Webb JL, Ravikumar B, Rubinsztein DC (2004) Microtubule disruption inhibits autophagosome-lysosome fusion: Impli- cations for studying the roles of aggresomes in polyglutamine diseases. Int J Biochem Cell Biol 36, 2541-2550.

[52] Klein RL, Dayton RD, Henderson KM, Petrucelli L (2006) Parkin is protective for substantia nigra dopamine neurons in a tau gene transfer neurodegeneration model. Neurosci Lett 401, 130-135.

[53] Ren Y, Jiang H, Yang F, Nakaso K, Feng J (2009) Parkin protects dopaminergic neurons against microtubuledepolymerizing toxins by attenuating microtubule-associated protein kinase activation. $J$ Biol Chem 284, 4009-4017.

[54] Petrucelli L, Dickson D, Kehoe K, Taylor J, Snyder H, Grover A, De Lucia M, McGowan E, Lewis J, Prihar G, Kim J, Dillmann WH, Browne SE, Hall A, Voellmy R, Tsuboi Y, Dawson TM, Wolozin B, Hardy J, Hutton M (2004) CHIP and Hsp70 regulate tau ubiquitination, degradation and aggregation. Hum Mol Genet 13, 703-714.

[55] Hatakeyama S, Matsumoto M, Kamura T, Murayama M, Chui DH, Planel E, Takahashi R, Nakayama KI, Takashima A (2004) U-box protein carboxyl terminus of Hsc70-interacting protein (CHIP) mediates poly-ubiquitylation preferentially on four-repeat Tau and is involved in neurodegeneration of tauopathy. J Neurochem 91, 299-307.

[56] Shimura H, Schwartz D, Gygi SP, Kosik KS (2004) CHIP-Hsc70 complex ubiquitinates phosphorylated tau and enhances cell survival. J Biol Chem 279, 4869-4876.

[57] Casarejos MJ, Solano RM, Rodriguez-Navarro JA, Gomez A, Perucho J, Castano JG, Garcia de Yebenes J, Mena MA (2009) Parkin deficiency increases the resistance of midbrain neurons and glia to mild proteasome inhibition: The role of autophagy and glutathione homeostasis. J Neurochem 110, 1523-1537. 